\title{
Online Alışveriş Niyetini Etkileyen Faktörlerin Planlı Davranışlar Teorisi ve Teknoloji Kabul Modelinin Entegrasyonu ile İncelenmesi*
}

\section{Investigation of Factors Affecting the Online Purchase Intention by the Integration of The Planned Behavior Theory and The Technology Acceptance Model}

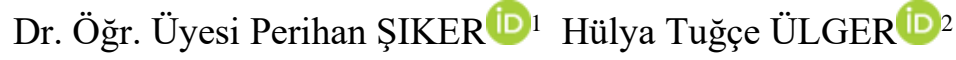

\begin{abstract}
$\ddot{O} z$
E-ticarette sürekli gelişim gösteren değişim ve yeniliklerin meydana gelmesiyle tüketicilerin bakış açıları günden güne değişmektedir. Bu çalışmanın temel amacı; İnternet üzerinden alışveriş yapan tüketicilerin, satın alma tutumları üzerinde etkili olan faktörleri tespit edip, katılımcıların bu faktörlere cinsiyet bazında farklı bakıp bakmadıklarına yönelik davranışlarını araştırmaktır. Bu amaçlar doğrultusunda araşıırmada, genel olarak literatürde araştırmacılar tarafından yaygın olarak kullanılan Teknoloji Kabul Modeli ve Planlı Davranışlar Teorisi dikkate alınarak hazırlanan anket formu Niğde Ömer Halisdemir Üniversitesi'nde akademik ve idari personele uygulanmıştır. Araştırma sonuçlarına göre tüketicilerin İnternetten satın alma davranışlarında cinsiyetler arasında algılanan haz, öznel norm ve algılanan güven faktörlerinde istatistiksel olarak anlamlı farklılıklar olduğu tespit edilmiştir. Ayrıca davranışsal niyet açısından en önemli faktörün algılanan kullanışlılık olduğu belirlenmiştir.
\end{abstract}

Anahtar Kelimeler: E-ticaret, tüketici davranışları, Teknoloji Kabul Modeli, Planlı Davranışlar Teorisi

Makale Türü: Araştırma

\begin{abstract}
With the emergence of changes and innovations that show continuous improvement in e-commerce, consumers ' perspectives are changing from day to day. The main purpose of this study is to determine the factors effecting the purchasing behavior of the consumers who are shopping online and to investigate whether the participants look at these factors differently on a gender basis. For this purpose, the questionnaire was prepared by taking into consideration the technology acceptance model and planned behavior theory widely used by researchers in the literature in general and applied to academic and administrative personnel at Nigde Ömer Halisdemir University. According to the results of the research, there were statistically significant differences in the satisfaction, subjective norm and perceived confidence factors perceived among sexes in consumers ' online buying behavior. In addition, it has been determined that the most important factor in terms of behavioral intentions is perceived usefulness.
\end{abstract}

Keywords: E-commerce, consumer behavior, Technology Acceptance Model, Planned Behavior Theory

Paper Type: Research

\footnotetext{
*Bu makale Hülya Tuğçe Ülger tarafindan Niğde Ömer Halisdemir Üniversitesi Sosyal Bilimler Enstitüsü’nde 25.06.2018 tarihinde savunulan Yüksek Lisans tezinden üretilmiștir.

${ }^{1}$ Niğde Ömer Halisdemir Üniversitesi, İletişim Fakültesi, perihanskr@ohu.edu.tr

${ }^{2}$ Niğde Ömer Halisdemir Üniversitesi, Sosyal Bilimler Enstitüsü, ulger_tugce@ hotmail.com
}

Atıf için (to cite): Şıker, P ve Ülger, H. T. (2019). Online Alışveriş Niyetini Etkileyen Faktörlerin Planlı Davranışlar Teorisi ve Teknoloji Kabul Modelinin Entegrasyonu ile İncelenmesi. Afyon Kocatepe Üniversitesi Sosyal Bilimler Dergisi, 21(4), 1246-1260. 


\section{Giriș}

İletişim ve bilgi teknolojilerinde meydana gelen hızlı gelişmeler her geçen gün yeniliklerin doğmasına yol açmaktadır. Bu yenilikler klasik birçok anlayışında değişimini zorunlu kılmaktadır. İletişim ve bilgi teknolojilerinde ortaya çıkan bu gelişmeler ve yenilikler, ticaretin şeklini de son 20 yıl içerisinde büyük oranda değiştirmiştir. İşletmeler açısından bakıldığında teknolojik gelişmeler sonucunda elektronik ortamlarda ticaret yapılır hale gelmiş, tüketiciler bulundukları yerden ihtiyaçlarını satın alabilir konuma gelmiştir. Mağazaya gitmeden, istenilen yerde ve istenilen zamanda alışveriş yapabilmek her ne kadar tüketiciler için cazip gözükse de halen geleneksel alışverişi online alışverişe tercih eden tüketicilerin sayısı da oldukça fazladır. $\mathrm{Bu}$ nedenle, e-ticarette büyümek isteyen perakendeciler için tüketicilerin online alışveriş niyetlerini etkileyen faktörlerin anlaşılması önem kazanmaktadır.

Teknoloji Kabul Modeli (Technology Acceptance Model: TAM) ve Planlı Davranışlar Teorisi (Theory of Planned Behavior: TPB) insanların yeni teknolojileri benimsemeleri ile ilgili niyetlerini belirlemeye yönelik temel oluşturan iki model olarak kabul edilmektedir. TAM, sıklıkla bilgi sistemleri ve diğer alanlar için kullanılmıştır (Davis, 1989). TPB modeli de çeşitli teknolojilerin tüketici tarafından kabul görmesini ele almak için pazarlama araştırması çalışmalarında önemli ölçüde kullanılan bir modeldir (Ajzen, 1991). Bu nedenle, bir çalışma yeni ortaya çıkan bir teknolojinin potansiyel olarak benimsenmesine odaklandığında hem TAM hem de TPB modelleri yararlı olmaktadır. TPB algılanan davranış kontrolü, öznel normlar ve tutum gibi faktörleri içerirken, TAM algılanan kullanışlılı̆̆ 1 ve algılanan kullanım kolaylığını içerir. Yabancı literatür incelendiğinde teknoloji kabulünde TAM ve TPB modellerine farklı değişkenler eklenerek yapıldığ 1 (Lu vd. 2010; Chen 2013; Elwalda vd. 2016; Ha vd. 2019; Fortes ve Rita, 2016) çalışmalara rastlanmaktadır. Ancak yerli literatürde TAM ve TPB modellerinin bir arada ele alındığı çalışma sayısı (Şahin ve Alkaya, 2017; Doğan vd. 2015) oldukça kısıtlıdır. Şahin ve Alkaya (2015), çalışmalarında bireylerin bilgi işlem teknolojileri kullanım niyetleri üzerinde algılanan kullanışlılık, algılanan kullanım kolaylığı, sübjektif norm, tutum ve algılanan davranışsal kontrolün etkilerini incelemişlerdir. Doğan vd. (2015) ise TAM ve TPB modellerini ilişkilendirerek müşterilerin internet bankacılığı kullanımındaki tutum ve davranışları açıklamaya çalışılmışlardır. Bu çalışmada, yerli literatürde ihmal edilen TAM ve TPB kuramları arasındaki korelasyon önemli bir perspektiften araştırılmaktadır. Bu amaçla, tüketicilerin internet üzerinden alışveriş niyetlerinde etkili etkili olan faktörleri belirlemek için TAM ve TPB modelleri ilişkilendirilmiş ve modele güven faktörü entegre edilerek analizler gerçekleştirilmiştir. Ayrıca önceki araştırmalar, tüketicilerin teknolojiyi kabul süreçlerinin belirlenmesinde cinsiyetin önemli bir rol oynadığını ileri sürmektedir (Venkatesh ve Morris, 2000; Venkatesh vd., 2003; Wang vd. 2009). Algılanan kullanışlılık, algılanan kullanım kolaylığı, öznel norm, algılanan davranışsal kontrol ve algılanan güvenin tüketicilerin internetten alışveriş niyeti üzerindeki etkilerinin araştırıldı ̆̆ı bu çalışmada aynı zamanda bu faktörlerin kadın ve erkeklerin satın alma niyetlerinde anlamlı bir fark yaratıp yaratmadığını yönelik analizler gerçekleştirilmiştir.

\section{Elektronik Ticaret Kavramı}

Günümüzde ticari ve sosyal ilişkileri değiştirerek dünyayı küreselleştiren teknolojik gelişmeler inanılması güç boyutlara ulaşmıştır. İçinde bulunduğumuz zamana teknoloji çağı, internet çağı gibi isimler verilmekte ve iletişim teknolojilerindeki gelişmeler gün geçtikçe insanlara ve işletmelere üstünlükler ve firsatlar sağlamaya devam etmektedir. İletişim teknolojilerindeki baş döndürücü gelişmeler hayatımızın her alanında büyük değişimlere neden olduğu gibi ticaret anlayışının ve ticaret şeklinin de değişmesine neden olmaktadır. Ticari faaliyetin en önemli adımları ve kısıtlarından, zaman ve mekân kavramlarından bağımsız, istenilen her anda ve istenilen her yerde gerçekleştirilen alışveriş işlemleri e-ticaret olarak tanımlanmaktadır. Web perakendecileri ile tüketiciler arasındaki online işlemler interaktif pazarlama iletişimine örnek olarak verilebilir (Pavlou vd.:2000). İnternet aracıllğıyla veri transferi yapabilen bilgisayar, cep telefonu veya benzeri bir cihazla gerçekleştirilen e-ticaret olgusu, klasik 
ticaret anlayışıyla ulaşılması imkânsız olan müşteri sayılarına erişilmesini sağlamakla birlikte çok sayıda değişik müşteri profilindeki kişilere satın alma işleminin gerçekleştirilmesine imkan sağlamaya başlamıştır. Ticaret, pazarlama boyutundan değerlendirildiğinde, İnternet ortamında gerçekleştirilmesine başlanan pazarlama eylemi, doğrudan pazarlama teknikleri adında yeni bir kavramı doğurmuştur. Bu yeni kavram, iş yeri tanımını ortadan kaldırmakla birlikte, satışa arz edilen ürünün sayısını ve hizmet çeşitlerinin sayısını sınırsız bir hale getirmiştir (Akçi ve Annaç Göv, 2015: 414). 21. yüzyılın ilk çeyreğinde bulunduğumuz bu günlerde bilgi ve iletişim teknolojileri ve internet her sektörü değiştirmeye başlayarak sosyal yaşantıdan iş yaşantısına, iletişimden eğlence dünyasına, sağlıktan eğitim hayatına kadar hayatımızın her alanında yeniliklere yol açmıştır. İnternetin yaygın olarak kullanılmasıyla iş hayatında ticari işlemler gerçekleştirilmesi sağlanarak e-ticaret kavramı hayatımıza girmiştir (Acılar, 2016: 281).

1990'lardan bu yana ülkemizde internet kullanımının yaygınlaşması ve internet altyapısındaki hızlı gelişme ve yatırımlara bağlı olarak dünyadaki gelişime paralel bir şekilde internet ticari amaçlar için de kullanılmaya başlanmış, internetin e-ticaret amaçlı kullanımı hem işletme hem de tüketicilerin iş ve alışveriş yapma şekillerini değiştirmiştir. Gün geçtikçe değişen hayat tarzları, zamanın hızı ve verimli bir şekilde kullanma baskısı gibi nedenler çok sayıda tüketicinin alışverişini elektronik ortamda (İnternet üzerinden) yapmayı seçmesi elektronik ticaretin gelişmesini hızlandıran en önemli etkenlerden biri olmuştur (Yayar ve Sadaklıŏglu, 2012: 146). Son dönemlerde e-ticaret daha çok tüketicinin dikkatini çekmiş ve yeni bir alışveriş tarzını ortaya çıkarmıştır. Online olarak yapılan alışveriş, gitgide artan bir ivmeyle tüketiciler tarafından kullanılarak, işletmelere ve pazarlamaya yeni firsatlar oluşturmuştur. Bu gelişmelere paralel olarak elektronik ticaret tüm dünyada olduğu gibi Türkiye'de de giderek yaygınlaşmaktadır (Serhateri, 2015: 228). Teknolojik altyapı ve cihazların atmasıyla birlikte İnternet kullanımındaki artıştan dolayı, dünyanın en kalabalık 19. Ülkesi olan ve 81 milyona yaklaşan nüfusuyla Türkiye'de 46,2 milyon internet kullanıcısı bulunmaktadır. Bu oranda dünyada en fazla internet kullanıcısına sahip olan 17. ülke olmamıza neden olmuştur (E-Ticaret Raporu, 2017).

TÜİK (2017) tarafindan yapılan "hane halkı bilişim teknolojileri kullanım araştırması2017" verilerine göre bilgisayar kullanım oranı 2017 yılında 16-74 yaş grubundaki bireylerde $\% 56,6$ İnternet kullanım oranı ise \%66,8 olmuştur. Bu oranlar 2016 yılında sırasıyla \%54,9 ve $\% 61,2$ idi. 16-74 yaş grubundaki erkeklerde bilgisayar ve İnternet kullanım oranları \%65,7 ve $\% 75,1$ iken, kadınlarda \%47,7 ve \%58,7 olmuştur. Araştırma sonuçlarına göre 10 hanenin 8'inde İnternet erişim imkânı bulunurken, Türkiye genelinde İnternet erişim imkanına sahip hanelerin oranı 2017 y1lı Nisan ayında \%80,7 olmuştur. Aynı araştırma sonuçlarına göre, her dört kişiden biri İnternetten alışveriş yapmıştır. 2017 yılında İnternet üzerinden mal ve hizmet satın alan 1674 yaş grubundaki bireylerin oranı \%24,9 olmuştur. 2016 y1lında bu oran ise \%20,9 olarak gerçekleşmiştir. Bir önceki yıla göre İnternetten alışveriş yapanların oranı $\% 4$ artmıştır. Bu artış oranı ile ülke nüfusunu oranladığımızda bir önceki (2016) yıla göre bir yılda 3 milyondan fazla kişi İnternet üzerinden alışveriş yapmaya başlamış olduğu anlaşılmaktadır.

\section{Planlı Davranışlar Teorisi ve Teknoloji Kabul Modeli}

TPB, birey davranışlarının şekillenmesinde birey iradesinin yanında diğer bazı faktörlerin de etkili olduğunu ifade etmektedir. Ajzen, Fishbein (1980) tarafından geliştirilen TPB bireyin davranışa yönelik niyetinin, tutumlar, öznel normlar ve algılanan davranışsal kontrol tarafından etkilenerek biçimlendiğini savunur (Ajzen, 1991). Tutum, bireyin belirli bir davranışı olumlu veya olumsuz değerlendirmesidir. Öznel normlar, insanların içinde yaşadığı toplumun davranış biçimlerine göre şekillenmiş inanç ve değerleridir. Algılanan davranışsal kontrol, bireylerin davranışı gerçekleştirmek için sahip olduğu şartlara yönelik inancını ifade etmektedir. Davranışsal niyet ise, bir bireyin belirli bir davranışı gerçekleştirmeye hazır olduğunun bir göstergesidir. Bununla birlikte, TPB'nin temel hipotezi, davranışların ortaya çıkmasının kişinin iradesinin iradi kontrolüne dayandığıdır (Fishbein ve Ajzen, 1975). Çetinkaya (2014), TPB'yi temel aldığı çalışmasında, üniversite öğrencilerinin girişimci olma niyetlerini, davranışa yönelik 

Integration of The Planned Behavior Theory and The Technology Acceptance Model

tutumlarının ve algılanan davranış kontrolünün pozitif yönde etkilediği, öznel normun ise istatistiksel olarak anlamlı olmadığ 1 sonucuna ulaşmıştır.

Davis (1989) tarafindan geliştirilen TAM'ın temel amacı tüketicilerin yeni teknolojileri benimsemesinde etkili olan faktörleri belirlemektir. (Al-Somali vd.,2009:132). TAM, teknoloji kullanma istek ve niyetlerini algılanan kullanışlılık, algılanan kullanım kolaylığ ile kişinin davranışa dönük niyetine dayanarak ölçmeyi amaçlayan bir teoridir (Legris vd., 2003; Chen vd. 2002; Yuanquan vd., 2008). Davis'e (1989) göre, algılanan kullanım kolaylığı, "bir kişinin belirli bir sistemi kullanmanın bir çaba gerektirmeyeceğine inandığı derece" olarak tanımlanırken, algılanan kullanışlılık ise "bir kişinin belirli bir sistemi kullanmasının iş performansını geliştireceğine inandığı derece" olarak tanımlanmaktadır. Daha sonraki çalışmalarda internet kullanımının kabulünde algılanan kullanım kolaylığı ve algılanan kullanışlılığın yanında algılanan hazzın da önemli bir etken olduğu ortaya koyulmuştur (Davis vd. 1992, Teo vd. 1999). Algılanan haz kişilerin internet üzerinden alışveriş yaparken duydukları zevk olarak tanımlanmaktadır ve kişilerin algıladıkları haz arttıkça satın alma niyetleri de artacaktır (Davis vd. 1992). Lee vd. (2001) çalışmalarında TAM'ı kabul etmekle birlikte, algılanan riskin algılanan kullanışlılığ 1 etkilediğini ifade etmişlerdir.

Türker ve Özaltın Türker (2013) yaptıkları çalışmada, TAM'ı kullanarak Türkiye'ye gelen turistlerin internet üzerinden turistik ürün alışveriş yapmalarında etkili olan faktörleri incelemişlerdir. Çalışmalarının sonucunda, turistlerin kullanışlılık, kullanım kolaylığ 1 , güven ve haz algılarının e-alışverişe ilişkin tutumlarını etkilediğini belirlemişlerdir. Ancak katılımcıların alışveriş niyetlerinin her zaman davranışa dönüşmediği ifade etmişlerdir. Ramayah ve Ignatius (2005) çalışmalarında algılanan kullanım kolaylığı ve algılanan haz ile online satın alma davranışı arasında pozitif bir ilişki olduğunu ancak algılanan kullanışlılık ile online satın alma davranışı arasında anlamlı bir ilişki olmadığını ortaya koymuşlardır. Yılmaz vd. (2010) çalışmalarında, eticarete ilişkin tüketicilerin niyetlerini belirleyen faktörler arasındaki ilişkileri açıklamaya çalışmışlardır. Çalışmaları sonucunda e-ticaret yapan tüketicilerin sistemi kullanmaya ilişsin algıladıkları risk düzeylerinin e-ticarete ilişkin tutumlarını negatif yönde etkilediğini belirtmişlerdir. Yılmaz ve Tümtürk (2015), İnternet üzerinden alışveriş yapan tüketicilerin niyetini etkileyen faktörler için, TAM'dan yola çıkarak yaptıkları araştırma sonucunda online alışveriş niyetini doğrudan etkileyen tutum ve güven değişkenlerinin niyet üzerinde anlamlı bir etkisi olduğunu, öznel norm değişkeninin ise niyet üzerinde anlamlı bir etkisinin bulunmadığını belirtmişlerdir.

E-ticaretin tüketiciler tarafindan benimsenmesini etkileyen faktörlerden birisi de güvenlik eksikliği korkusudur. Algılanan güven bir tüketicinin internet üzerinden alışveriş niyetini doğrudan ya da dolaylı olarak etkilemektedir (Kim vd. 2008:17). Kim vd. (2010), araştırmalarında tüketicilerin turizm ürün ve hizmetlerini internet üzerinden satın almalarında algıladıkları güvenin müşteri memnuniyeti üzerinde önemli bir rol oynadığını ortaya koymuşlardır. Ustasüleyman ve Eyüboğlu (2010) TAM'1 kullanarak İnternet bankacılığının benimsenmesini etkileyen faktörleri araştırdıkları çalışmalarında, algılanan kullanım kolaylığı ve algılanan kullanışlılık değiş̧kenlerine güven ve algılanan web güvenliği değiş̧kenlerini de eklemişlerdir. Araştırma sonuçları algılanan kullanışlılığının güven üzerinde pozitif etkisi olduğunu göstermektedir. Kim vd. (2008), araştırmalarında bir tüketicinin güven algısının alışveriş niyeti üzerinde güçlü bir pozitif etkiye sahip olduğunu ve bir tüketicinin algıladığı risk ile arasında güçlü bir negatif ilişkinin olduğu belirlemişlerdir. Aynı zamanda tüketicilerin algıladığı riskin satın alma niyetini azalttığını, tüketicilerin algıladığı faydanın satın alma niyetini artırdığını ifade etmişlerdir.

Lu vd. (2010), TAM ve TPB modellerini bir arada kullandıkları çalışmalarında algılanan kullanışlılık ve algılanan kullanım kolaylığının algılanan davranışsal kontrol üzerinde pozitif etkisi olduğunu, öznel norm ve ahlaki normların kişinin davranış niyetlerini etkilediğini ortaya koymuşlardır. Çalışmalarında aynı zamanda TPB ve TAM'ın entegrasyonunun insan davranışlarını açıklayabildiğini ve tahmin edebileceğini ifade etmişlerdir. Elwalda vd. (2016) çevrimiçi müşteri yorumlarının tüketicilerin satın alma niyetleri üzerindeki etkisini incelemek için 
TAM modeline TPB modelinden algılanan kontrolün dahil edilmesine dayanan, Algilanan Türetilmiş Nitelikler (PDA) modelini geliştirmişlerdir. Çalışmadan elde edilen bulgular, müşterilerin bir e-satıcıya duyduğu güvenin ve internetten alışveriş yapma niyetlerinin algılanan kullanışlılık, algılanan kullanım kolaylığı ve algılanan hazdan önemli ölçüde etkilendiğini göstermektedir. Ha vd. (2019), TAM ve TPB modellerine dayanarak farklı faktörlerin Vietnamlı tüketicilerin online alışveriş niyetleri üzerindeki etkilerini araştırmışlardır. Sonuçlar, algılanan fayda, algılanan kullanım kolaylığı, tutum, öznel norm ve güvenin tüketicilerin online alışveriş niyetini olumlu yönde etkilediğini göstermektedir. Şahin ve Alkaya (2017), tüketicilerin Başbakanlık İletişim Merkezi (BİMER) çevrimiçi şikayet kanalını kullanımını etkileyen faktörleri TPB ve TAM kullanarak incelemişler ve araştırma sonucunda öznel norm, tutum, algılanan davranışsal kontrol ve algılanan faydanın tüketicilerin niyetleri üzerinde etkili olduğunu ifade etmişlerdir. Doğan vd. (2015), TAM ve TPB'yi ilişkilendirerek müşterilerin internet bankacılığı kullanımındaki tutum ve davranışlarını inceledikleri çalışmada, kişisel norm, algılanan kullanım kolaylığı ve algılanan davranışsal kontrolün internet bankacılığı kullanma niyeti üzerinde anlamlı etkisi olduğunu belirlemişlerdir.

\section{Teknoloji Kabulünde Cinsiyet Faktörü}

Pazarı segmentlere ayırmak için birçok yol olmasına rağmen günümüzde ürünlerin pazarlaması hala ağırlıklı olarak tüketicilerin demografik özelliklerine dayanmaktadır. Gelir, yaş, cinsiyet, etnik köken, medeni durum ve hane halkı büyüklüğü gibi demografik değişkenler yaygın olarak pazarlamacılar tarafından tüketici pazarlarını bölümlendirmek için kullanılmaktadır. $\mathrm{Bu}$ değişkenler arasında cinsiyet, ürün ve hizmetlerin önemli bir bölümü için Pazar bölümlendirmenin en popüler biçimlerinden biri olmuştur ve olmaya da devam etmektedir (Mokhlis ve Salleh, 2009). Campbell (1997), kadınlarla erkeklerin alışveriş konusunda taban tabana zıt değişkenlere sahip olduğu, erkeklerin alışveriş davranışı ile ilgili algılamalarının kadınlardan farklı bir ideolojiye sahip olduğunu öne sürmüştür. Kadınlar alışverişi istek ve arzularını tatmin etmede eğlenceli bir durum olarak algılarken, erkekler alışverişi ihtiyaçlarını gidermek için zorunlu bir aktivite olarak görmektedir (Campbell, 1997). Kadınlar alışveriş için zaman harcamaktan zevk almakta, erkekler ise mümkün olduğu kadar en hızlı şekilde alışveriş yapmak istemekte ve alışveriş yapmaktan hoşlanmamaktadırlar. Erkeklerin kadınlara göre alışveriş yaparken daha az zaman harcamalarına rağmen kadınlara göre daha fazla harcama yaptıkları görülmüştür (Fischer ve Arnold, 1990). Bae ve Lee (2011) çalışmalarında, kadın ve erkek tüketicilerin internet üzerinden alışveriş yapma istekleri arasında önemli bir farklılık olmadığını, kadınların da erkekler kadar internet üzerinden alışveriş yapma isteğinde olduğunu belirtmişlerdir. Aynı zamanda kadınların online alışverişte diğer tüketicilerin değerlendirmelerinden erkeklere göre daha fazla etkilendiklerini ortaya koymuşlardır. Benzer şekilde Garbarino ve Strahilevitz da (2004), kadınların bir ürünle ilgili arkadaşlarından gelen geri bildirimlerden erkeklere oranla daha fazla etkilendiklerini belirtmişlerdir. Araştırma bulgularına göre, kadınlar erkeklere göre online alışverişi daha riskli bulmakla beraber çevresindeki kişilerin önerileriyle online alışveriş isteklerinde artış olmaktadır. Venkatesh ve Morris (2000), TAM'1 kullanarak işyerinde teknolojinin bireysel olarak benimsenmesi ve sürekli kullanılmasında cinsiyet farklılıklarını araştırmışlardır. Araştırma sonucunda, algılanan kullanışlılığın teknoloji kullanma kararlarında kadınlara göre erkeklerde daha etkili olduğu, buna karşın kadınların teknoloji kullanma kararlarında öznel normdan daha fazla etkilendikleri sonucuna ulaşmışlardır. Wang vd. ise (2009), Tayvan'da yaptıkları araştırmada öznel normun mobil öğrenmeye yönelik davranış niyetlerinde erkeklerde kadınlara göre daha güçlü bir belirleyici olduğunu keşfetmişlerdir. Yang (2005), öğrencilerin e-ticarete yönelik tutumlarını araştırmak için TAM'1 kullanmış ve regresyon analizi sonucunda erkeklerin e-ticareti kadınlardan daha olumlu algıladıklarını ortaya koymuştur. Jones vd. (2009), erkeklerin interneti daha sık kullandığını ve sonuç olarak e-ticaret sitelerini kullanımlarının da çok yüksek olduğunu iddia etmişlerdir. Demirel (2010), çalışmasında erkek öğrencilerin kız öğrencilere göre internet üzerinden alışveriş yapmada daha cesaretli davrandıklarını ifade etmiştir. Özgüven'de (2011) benzer şekilde, tüketicilerin online alışverişe karşı tutumlarının cinsiyete göre farklılık gösterdiğini, kadınların 
erkeklere göre daha çok online alışveriş yaptıkları sonucuna ulaşmıştır. Bae ve Lee (2011) çalışmalarında, kadınların e-ticarete daha riskli baktığını ve gizlilik sorunları ile daha çok ilgili olduğunu fark etmiş̧lerdir. Aynı zamanda çalışmaları sonucunda kadınların çevrimiçi alışveriş yaparken olumsuz yapılan online tüketici yorumlarından erkeklerden daha fazla etkilendiğini belirtmiş̧lerdir. Aydın ve Derer (2015) yaptıkları araştırmada, üniversite öğrencilerinin internetten alışveriş yapma tutumları ile cinsiyet arasında anlamlı bir farklılık olduğu ve kadınların internetten alışveriş yapmayı erkeklere oranla daha fazla tercih ettikleri sonucuna ulaşmışlardır. Akçi ve Annaç Göv (2015) çalışmalarında, tüketicilerin e-ticarete ilişkin görüşlerinin belirlenmesi ile cinsiyet arasında anlamlı farklılıklar olduğunu ve online alışveriş şeklini erkeklerin kadınlara göre daha yüksek düzeyde tercih ettiğini tespit etmişlerdir. Goswami ve Dutta (2016), elektronik ticaret alanlarında kadınların ve erkeklerin çevrimiçi olarak online alışverişi aynı şekilde kullanıldığını ancak tüketici yorumlarından kadınların erkeklerden daha fazla etkilendiğini ifade etmişlerdir. Hem kadın ve erkek tüketicilerin alışveriş davranışlarındaki bu farklı1ıklar hem de çalışma evrenini oluşturan katılımcı grubunun gelir ve yaş gibi diğer demografik özelliklerinin daha homojen bir dağılım göstermesi nedeniyle bu çalışmada cinsiyet faktörü üzerine yoğunlaş1lmıştır.

\section{Araştırmanın Yöntemi}

$\mathrm{Bu}$ araştırma, İnternet üzerinden alışveriş yapan tüketicilerin, satın alma niyetleri üzerinde etkili olan faktörleri tespit edip, katılımcıların bu faktörlere demografik özelliklerinden cinsiyet bazında farklı bakıp bakmadıklarına yönelik davranışlarını araştırmak amacıyla yapılmıştır. Araştırmada veri toplama yöntemi olarak birincil veri toplama yöntemi olan anket yöntemi kullanılmıştır. Anket uygulaması Niğde Ömer Halisdemir Üniversitesi'nde çalışmakta olan ve İnternet üzerinden satın alma davranışı gerçekleştiren akademik ve idari personelle 05.03.2018 ile 30.03.2018 tarihleri arasında gerçekleştirilmiştir. Araştırma için üniversite personelinin tercih edilmesinde, genel olarak üniversite personelinin bilgi ve iletişim teknolojilerini yoğun olarak kullanması, çalışma şartları ve saatleri nedeniyle kısıtlı zamana sahip olunması gibi nedenlerden dolayı online alışveriş yapma olasılıklarının fazla olacağı düşüncesi etkili olmuştur. Niğde Ömer Halisdemir Üniversitesi Personel Dairesi Başkanlığı'ndan alınan verilere göre anketin yapıldığı tarihler arasında, üniversitede 1593 akademik ve idari personel bulunmaktadır. Örneklem büyüklüğü \%95 güven aralığı ve $\% 5$ hata payı ile 310 olarak hesaplanmıştır. Anket uygulaması kolayda örnekleme yöntemi ile belirlenen ve daha önce internetten en az bir kez alışveriş̧ yaptığını ifade eden 310 katılımcı ile yüz yüze gerçekleştirilmiştir. Elde edilen verilerin analizinde SPSS 19.0 istatistik programı kullanılarak frekans dağılımı, faktör analizi, $t$ testi ve regresyon analizlerinden yararlanılmıştır.

Araştırma modeli, bilgi teknolojilerinin benimsenmesinde, araştırmalarda sıklıkla kullanılan TAM ile bireylerin davranışlarında özel norm ve algılanan davranış kontrolü gibi faktörleri de içeren TPB modelleri dikkate alınarak oluşturulmuştur. Araştırmada kullanılan anket formu iki bölümden oluşmakta olup ilk bölümde cinsiyet, yaş, aylık gelir gibi demografik bilgilere, ikinci bölümde ise internet üzerinden alışveriş ile ilgili 32 adet 5'li Likert ölçeğinde yargıya yer verilmiş̧ir. TAM içerisinde yer alan algılanan kullanışlılık ve algılanan kullanım kolaylığı ile ilgili soruların hazırlanmasında Davis (1989) ile Pikkarainen vd. (2004) çalışmalarından, algılanan haz Davis vd. (1992), güven ile ilgili Kim vd. (2008), öznel norm ve algılanan davranışsal kontrol ile ilgili soruların hazırlanmasından ise Ajzen, I.(1991) çalışmasından yararlanılmıştır. İnternetten satın almaya niyetine ilişkin ifadeler için Joo ve Sang '1n (2013), Davis (1989) çalışmalarından yararlanılmıştır. Araştırmanın amacı doğrultusunda algılanan kullanışlılık, algılanan kullanım kolaylığı, algılanan güven, algılanan davranışsal kontrol, algılanan haz ve öznel norm faktörlerinin tüketicilerin satın alma niyetleri üzerindeki etkilerini belirlemek ve bu faktörlerin tüketicilerin cinsiyetlerine göre farkl1lı gösterip göstermediğini araştırmak için aşağıdaki hipotezler geliştirilmiştir.

$\mathrm{H}_{1}$ : Algılanan kullanışlılık tüketicilerin İnternetten satın alma niyetleri üzerinde anlamlı bir etkiye sahiptir. 

sahiptir.

$\mathrm{H}_{2}$ : Algılanan haz tüketicilerin İnternetten satın alma niyetleri üzerinde anlamlı bir etkiye

$\mathrm{H}_{3}$ : Algılanan güven tüketicilerin İnternetten satın alma niyetleri üzerinde anlamlı bir etkiye sahiptir.

$\mathrm{H}_{4}$ : Algılanan kullanım kolaylığı tüketicilerin İnternetten satın alma niyetleri üzerinde anlamlı bir etkiye sahiptir. sahiptir.

$\mathrm{H}_{5}$ : Öznel norm tüketicilerin İnternetten satın alma niyetleri üzerinde anlamlı bir etkiye

$\mathrm{H}_{6}$ : Algılanan davranışsal kontrol tüketicilerin İnternetten satın alma niyetleri üzerinde anlamlı bir etkiye sahiptir.

$\mathrm{H}_{7}$ : İnternet üzerinden alışverişte tüketicilerin cinsiyetlerine göre algılanan kullanışl1lık farkl111k gösterir.

$\mathrm{H}_{8}$ : İnternet üzerinden alışverişte tüketicilerin cinsiyetlerine göre algılanan haz farklılık gösterir.

$\mathrm{H}_{9}$ : İnternet üzerinden alışverişte tüketicilerin cinsiyetlerine göre algılanan güven farkl111k gösterir.

$\mathrm{H}_{10}$ : İnternet üzerinden alışverişte tüketicilerin cinsiyetlerine göre algılanan kullanım kolaylığı farklılık gösterir. gösterir.

$\mathrm{H}_{11}$ : İnternet üzerinden alışverişte tüketicilerin cinsiyetlerine göre öznel norm farkl11ık

$\mathrm{H}_{12}$ : İnternet üzerinden alışverişte tüketicilerin cinsiyetlerine göre algılanan davranışsal kontrol farklılık gösterir.

\section{Bulgular ve Tartışma}

Anket formları ile elde edilen verilerin bilgisayar ortamına aktarılmasında ve sonuçların analiz edilmesinde SPSS 19.0 programı kullanılmıştır.

Tablo 1. Kat1lımcıların demografik özellikleri

\begin{tabular}{llcc}
\hline \multicolumn{2}{c}{ Demografik Özellikler } & Frekans & \% \\
\hline \multirow{2}{*}{ Cinsiyet } & Kadın & 121 & 39 \\
& Erkek & 189 & 61 \\
\hline \multirow{2}{*}{ Yaş } & 35 ve altı & 110 & 35,5 \\
& $36-45$ & 104 & 33,5 \\
\multirow{2}{*}{ Çalış1lan Birim } & 46 ve üzeri & 96 & 31 \\
\hline \multirow{2}{*}{ Gelir Düzeyi } & Fakülte & 176 & 56,8 \\
& MYO & 134 & 43,2 \\
\hline
\end{tabular}

Ankete katılanların demografik özellikleri Tablo 1'de sunulmuştur. Ankete katılan 310 kişinin \%39'u kadın, \%61'i erkek katılımcıdan oluşmaktadır. Katılımcıların \%35,5'i 35 yaş altı, \%33,5'i 36-45 yaş arası, \%31'i ise 46 yaş ve üzeridir. Katılımcıların \%56,8'i fakültede çalışmakta olup \%56,8'inin gelir düzeyi 4000 TL ve üzeridir. 
Tablo 2. Katılımcıların internet üzerinden alışveriş yaptıkları ürün gruplarının dağılımı

\begin{tabular}{lcccc}
\hline \multirow{2}{*}{\multicolumn{1}{c}{ Ürün grubu }} & \multicolumn{2}{c}{ Kadın } & \multicolumn{2}{c}{ Erkek } \\
\cline { 2 - 5 } & Evet & Hayır & Evet & Hayır \\
\hline 1. Giyecek, ayakkabı, çanta vb. ürünler & 97 & 4 & 104 & 85 \\
\hline 2. Kitap, CD, DVD vb. ürünler & 72 & 49 & 109 & 80 \\
\hline 3. Ev aksesuarları, mobilya, beyaz eşya vb. ürünler & 42 & 79 & 50 & 139 \\
\hline 4. Cep telefonu, bilgisayar vb. teknolojik ürünler & 27 & 94 & 98 & 91 \\
\hline 5. Gıda ve temizlik ürünleri & 12 & 109 & 26 & 163 \\
\hline 6. Kozmetik ve kişisel bakım ürünleri & 45 & 76 & 41 & 148 \\
\hline 7. Online yemek siparişi & 10 & 111 & 17 & 172 \\
\hline 8. Çiçek & 12 & 109 & 19 & 170 \\
\hline
\end{tabular}

Tablo 2'de araştırmaya katılan tüketicilerin İnternet üzerinden çoğunlukla satın aldıkları ürün gruplarının cinsiyete göre dağılımı incelendiğinde, kadınların daha çok giyecek, ayakkabı, çanta vb. ürünleri satın aldıkları, erkeklerin ise daha çok kitap, CD, DVD vb. ürünler satın aldıkları belirlenmiştir.

Literatürde cinsiyet ile satın alınan ürünler arasındaki ilişkiler incelendiğinde, Uzel ve Aydoğdu (2010), çalışmalarında demografik sorulara verilen cevaplara göre cinsiyetin daha çok satın alınan ürün türlerinde farklılık gösterdiği sonucuna ulaşmışlardır. Kadınların daha çok aksesuar, giyim, kozmetik alışverişi yaptığını, erkeklerin ise daha çok elektronik ürün alışverişi yaptığını ifade etmişlerdir. Demirel (2010) üniversite öğrencileriyle yapmış olduğu çalışmasında, hem kız hem de erkek öğrencilerin elektronik alışverişte en fazla kitap satın aldığını belirtmiştir. Akçi ve Annaç Göv (2015) araştırmalarında, erkeklerin elektronik ürünler ile bilet, seyahat, konser ürünlerini daha yüksek düzeyde satın aldıklarını, kadınların ise giyim, moda, aksesuar ürünlerini daha fazla satın aldığını ifade etmişlerdir.

Hipotez testlerine geçmeden önce araştırmada kullanılan ölçeklerin faktör yapılarını belirlemek için keşifsel faktör analizi yapılmış ve keşifsel faktör analizi sonucunda ortaya çıkan yapıya bağlı olarak ölçeklerin güvenilirliğini test etmek için iç tutarlılık metotlarından biri olan Cronbach's Alfa Katsayısı kullanılmıştır. Bağımsız değişkenlerin güvenilirlik değeri $\alpha=0.920$, bağımlı değişken "Davranışsal niyet" değişkeninin güvenilirlik değeri ise $\alpha=0,855$ olmuştur.

Faktör analizi sonuçlarını değerlendirebilmek için faktör analizinin ön koşulları olan Kaiser-Meyer-Olkin (KMO) örneklem yeterliliği ve Barlett küresellik testi sonuçları incelenmiştir. Tüketicilerin internet üzerinden satın alma davranışlarını etkileyen faktörler ve davranışsal niyet için elde edilen sonuçlar veri setinin faktör analizine uygunluğunu göstermektedir. $(\mathrm{KMO}=, 885$; Bartlett's Test of Sphericity: Approx. Chi-Square $=4185,942$ $\mathrm{df}=351 ; \mathrm{Sig}=0,00) . \quad(\mathrm{KMO}=, 850$; Bartlett's Test of Sphericity: Approx. Chi-Square $=852,151$; $\mathrm{df}=15 ; \mathrm{Sig}=0,00)$. 
Tablo 3. Faktör analizi değerlendirmesi

\begin{tabular}{|c|c|c|c|}
\hline Faktörler & İfadeler & $\begin{array}{l}\text { Faktör } \\
\text { Yükü }\end{array}$ & $\begin{array}{l}\text { Cronbach's } \\
\text { Alpha }\end{array}$ \\
\hline \multirow{6}{*}{$\begin{array}{l}\text { Algılanan } \\
\text { Kullanım } \\
\text { Kolaylığı }\end{array}$} & İnternetteki alışveriş sitelerinde ürünleri daha ucuza bulabilirim. & 0,817 & \\
\hline & İnternetteki alışveriş siteleri ürün aramada ve satın almada daha kullanışlıdır. & 0,804 & \\
\hline & İnternetteki alışveriş sitelerini kullanmak kolaydır. & 0,757 & \\
\hline & İnternet üzerinden alışveriş yapmak bana zaman kazandırır. & 0,751 & \\
\hline & $\begin{array}{l}\text { İnternet üzerinden alışverişte ürünler arasında karşılaştırma yapmak kolaydır. } \\
\text { İnternetteki alışveriş sitelerinin tüketiciler açısından faydalı olduğunu } \\
\text { düşünüyorum. }\end{array}$ & $\begin{array}{l}0,743 \\
0,71\end{array}$ & \\
\hline & $\begin{array}{l}\text { İnternetteki alışveriş siteleri ürünler hakkında bilgi almak ve onları satın almak için } \\
\text { elverişlidir. }\end{array}$ & 0,699 & 0,902 \\
\hline \multirow{4}{*}{$\begin{array}{l}\text { Alglanan } \\
\text { Haz }\end{array}$} & İnternet üzerinden alışveriş gerçek mağazadan alışverişe göre daha zevklidir. & 0,916 & \\
\hline & İnternet üzerinden alışveriş gerçek mağazadan alışverişe göre daha eğlencelidir. & 0,886 & \\
\hline & İnternet üzerinden alışveriş gerçek mağazadan alışverişe göre daha ilginçtir & 0,799 & \\
\hline & İnternet üzerinden alışveriş yapmaktan keyif alırım. & 0,602 & 0,832 \\
\hline \multirow{5}{*}{ Güven } & İnternette alışveriş sitelerinde yeterli güvenlik önlemleri bulunmaktadır. & 0,846 & \\
\hline & Alışveriş yaptığım alışveriş sitelerinin güvenliğinden eminim. & 0,808 & \\
\hline & Alışveriş yaparken bilgilerin gizliliğinin korunduğunu düşünüyorum. & 0,801 & \\
\hline & İnternetteki alışveriş sitelerinden ödeme yapmak güvenilirdir & 0,769 & \\
\hline & Alışveriş yaptığım internet sitelerinin güvenilirliği ile ilgili endişe duymam. & 0,743 & 0,891 \\
\hline \multirow{4}{*}{$\begin{array}{l}\text { Algılanan } \\
\text { Kullanışlılık }\end{array}$} & Alışveriş siteleri satın alma işlemlerini hızlı ve etkin yürütür. & 0,762 & \\
\hline & Alışveriş yaptığım sitelerin web tasarımları rahat işlem yapmaya uygundur. & 0,752 & \\
\hline & Alışveriş sitesi üzerinden satın alma işlemlerini yapmak çok kolaydır. & 0,689 & \\
\hline & $\begin{array}{l}\text { Alışveriş sitelerinin müşteri hizmetleri etkilidir. } \\
\text { İternet üzerinden yaptığım alışverişlerde siteyle ilgili herhangi bir sorun } \\
\text { yaşamadım. }\end{array}$ & 0,571 & 0,775 \\
\hline \multirow{3}{*}{ Öznel Norm } & İnternetten alışveriş yapacağım zaman başkalarının tavsiyelerini dikkate alırım & 0,877 & \\
\hline & İnternetten alışveriş yapmamda arkadaş çevremin etkisi vardır. & 0,818 & \\
\hline & $\begin{array}{l}\text { Düşüncelerine önem verdiğim kişilerin internet üzerinden alışveriş deneyimleri } \\
\text { tercihlerimi etkiler. }\end{array}$ & 0,809 & 0,813 \\
\hline \multirow{2}{*}{$\begin{array}{l}\text { Algılanan } \\
\text { Davranışsal } \\
\text { Kontrol }\end{array}$} & İnternetten alışveriş yaparken tüketici haklarımın neler olduğunu biliyorum. & 0,725 & \\
\hline & İnternetten alışveriş yaparken kontrol tamamen bendedir. & 0,573 & 0,639 \\
\hline \multicolumn{4}{|c|}{ Toplam Açılanan Varyans: \%64,025; KMO=,885; Sig. $=, 000$} \\
\hline $\begin{array}{l}\text { Bağımlı } \\
\text { Değişken }\end{array}$ & İfadeler & $\begin{array}{c}\text { Faktör } \\
\text { Yükü }\end{array}$ & $\begin{array}{c}\text { Cronbach's } \\
\text { Alpha }\end{array}$ \\
\hline \multirow{5}{*}{$\begin{array}{l}\text { Davranışsal } \\
\text { Niyet }\end{array}$} & Yakın bir zamanda yine internetten ürün satın almayı düşünüyorum. & 0,854 & \multirow{5}{*}{0,855} \\
\hline & İnternet üzerinden alışveriş yapmaya devam edeceğim. & 0,851 & \\
\hline & $\begin{array}{l}\text { Çevremdekileri internet üzerinden alışverişi tavsiye ederim. } \\
\text { İternetten alışveriş yapmaya başladığımdan bu yana gerçek mağazalardan çok } \\
\text { fazla alışveriş yapmıyorum }\end{array}$ & 0,83 & \\
\hline & Gerçek mağazada aynı ürün olsa bile internetten alış veriş yapmayı tercih ederim. & 0,681 & \\
\hline & İnternetten alıșveriș yapmanın iyi bir fikir olduğunu düșünüyorum. & 0,635 & \\
\hline
\end{tabular}

Faktör analizi sonrasında bağımsız değişkenlerin (algılanan davranışsal kontrol, algılanan haz, algılanan kullanışlılık, algılanan kullanım kolaylı̆̆ı, algılanan güven, özel norm,) bağımlı değişken (davranışsal niyet) üzerindeki etkisini ölçmek amacıyla çoklu regresyon analizi gerçekleştirilmiştir. 

Integration of The Planned Behavior Theory and The Technology Acceptance Model

Tablo 4. Çoklu regresyon analizi tablosu

\begin{tabular}{lccccc} 
Değissken & $\mathbf{B}$ & Standart Hata & $\boldsymbol{\beta}$ & $\mathbf{t}$ & $\mathbf{p}$ \\
\hline Sabit & $-0,223$ & 0,248 & & $-0,898$ & 0,37 \\
\hline Algılanan Kullanışlılık & 0,333 & 0,057 & 0,303 & 5,827 & 0 \\
\hline Algılanan Haz & 0,185 & 0,042 & 0,216 & 4,452 & 0 \\
\hline Algılanan Güven & 0,27 & 0,05 & 0,269 & 5,436 & 0 \\
\hline Algılanan Kullanım Kolaylı̆̆ı & 0,135 & 0,068 & 0,111 & 1,986 & 0,048 \\
\hline Öznel Norm & 0,131 & 0,037 & 0,16 & 3,502 & 0,001 \\
\hline Algılanan Davranıșsal Kontrol & 0,073 & 0,05 & 0,081 & 1,451 & 0,148 \\
\hline
\end{tabular}

Not: $\mathrm{R}^{2}=0,488 ; \mathrm{F}=49,902 ; \mathrm{F}$ Anlamlılı $\breve{g}_{1}=0,000$

Yapılan regresyon analizi sonucunda $\mathrm{R}^{2}$ katsayısı 0,488 olmuştur ve elde edilen bu sonuç altı bağımsız değişkenin davranışsal niyeti 0,488 oranında açıkladığını ifade etmektedir. Regresyon analiz sonuçları, tüketicilerin internet üzerinden alışveriş yapma niyetleri üzerinde; algılanan kullanışlılık $(\beta=0,303, p<0.01)$, algılanan haz $(\beta=0,216, p<0,01)$, algılanan güven $(\beta=0,269, p<0,01)$, algılanan kullanım kolaylığ $(\beta=0,111, p<0,05)$ ve öznel norm $(\beta=0,160$, $\mathrm{p}<0,01)$ değişkenlerinin istatistiksel olarak anlamlı bir etkiye sahip olduğunu göstermektedir. Analiz sonuçlarına göre $\mathrm{H}_{1}, \mathrm{H}_{2} \mathrm{H}_{3}, \mathrm{H}_{4}$ ve $\mathrm{H}_{5}$ hipotezleri kabul edilmektedir. Bağımsız değişkenler içerisinde sadece algılanan davranışsal kontrol değişkeninin $(\beta=0,081, p>0,05)$ davranışsal niyet üzerinde anlamlı bir etkisi olmadığ sonucuna ulaşılmıştır. Bu durumda " $\mathrm{H}_{6}$ : Algılanan davranışsal kontrol internetten satın alma tutumları üzerinde anlamlı bir etkiye sahiptir." hipotezi kabul edilmemiştir.

Tüketicilerin İnternet üzerinden satın alma davranışlarında etkili olan faktörlerin cinsiyete göre farklılık gösterip göstermediği ise bağımsız örneklem t-testi ile ölçülmüştür.

Tablo 5. Cinsiyet açısından t-testi sonuçları

\begin{tabular}{|c|c|c|c|c|c|}
\hline Faktör & Cinsiyet & $\mathbf{N}$ & Ortalama & $\mathbf{t}$ & $\mathbf{P}$ \\
\hline \multirow{2}{*}{ Algılanan Kullanışlılık } & Kadın & 121 & 4,0485 & \multirow{2}{*}{0,388} & \multirow{2}{*}{0,698} \\
\hline & Erkek & 189 & 4,0137 & & \\
\hline \multirow{2}{*}{ Algılanan Haz } & Kadın & 121 & 3,9357 & \multirow{2}{*}{$-2,163$} & \multirow{2}{*}{0,015} \\
\hline & Erkek & 189 & 3,1093 & & \\
\hline \multirow{2}{*}{ Güven } & Kadın & 121 & 3,0339 & \multirow{2}{*}{$-2,001$} & \multirow{2}{*}{0,047} \\
\hline & Erkek & 189 & 3,2987 & & \\
\hline \multirow{2}{*}{ Algılanan Kullanım Kolaylığı } & Kadın & 121 & 3,6839 & \multirow{2}{*}{0,535} & \multirow{2}{*}{0,593} \\
\hline & Erkek & 189 & 3,6407 & & \\
\hline \multirow{2}{*}{ Öznel Norm } & Kadın & 121 & 3,7482 & \multirow{2}{*}{$-4,089$} & \multirow{2}{*}{0,032} \\
\hline & Erkek & 189 & 3,1796 & & \\
\hline \multirow{2}{*}{ Algılanan Davranışsal Kontrol } & Kadın & 121 & 3,5625 & \multirow{2}{*}{1,167} & \multirow{2}{*}{0,244} \\
\hline & Erkek & 189 & 3,4341 & & \\
\hline
\end{tabular}

Tablo 5'te, algılanan kullanışl1lık ortalamalarına ilişkin sonuçlara göre kadınlar ve erkekler arasında anlamlı bir farklılık bulunmamaktadır $(\mathrm{p}=0,698>0,05)$. Kadınların ortalaması daha yüksek olduğu için kadınlar internetten alışverişi erkeklere göre daha fazla kullanışlı bulmaktadır fakat bu anlamlı bir farklılık oluşturmamaktadır. Bu durumda " $\mathrm{H}_{7}$ : İnternet üzerinden alışverişte tüketicilerin cinsiyetlerine göre algılanan kullanışlılık farklılık gösterir." hipotezi reddedilmiştir. Algılanan haz ortalamalarına ilişkin sonuçlar incelendiğinde kadınlar ile erkeler arasında anlamlı bir farklılık olduğu görülmektedir $(\mathrm{p}=0,015<0,05)$. Kadınların ortalamasının daha yüksek olması kadınların internetten alışveriş yaparken erkeklere göre daha fazla keyif aldıklarını göstermektedir. Buna göre " $\mathrm{H}_{8}$ : İnternet üzerinden alışverişte tüketicilerin cinsiyetlerine göre algılanan haz farklılık gösterir." hipotezi kabul edilmektedir. Katılımcıların cinsiyeti ile algılanan güven arasında da anlamlı bir farklılık bulunmaktadır ( $\mathrm{p}=0,047<0,05)$. Erkekler internetten alışverişi kadınlara göre daha güvenli bulmaktadır ve " $\mathrm{H}_{9}$ : İnternet üzerinden 
alışverişte tüketicilerin cinsiyetlerine göre algılanan güven farklılık gösterir." hipotezi kabul edilmektedir. Katılımcıların cinsiyeti ile algılanan kullanım kolaylığı $(\mathrm{p}=0,593>0,05)$ ve algılanan davranışsal kontrol $(\mathrm{p}=0,244>0,05)$ arasında anlamlı bir farklılık bulunmamaktadır. $\mathrm{Bu}$ durumda " $\mathrm{H}_{10}$ : İnternet üzerinden alışverişte tüketicilerin cinsiyetlerine göre algılanan kullanım kolaylığ farklılık gösterir." " $\mathrm{H}_{12}$ : İnternet üzerinden alışverişte tüketicilerin cinsiyetlerine göre algılanan davranışsal kontrol farklılık gösterir." hipotezleri reddedilmiştir. Öznel norm ortalamalarına göre katılımcıların cinsiyeti ile öznel norm) arasında anlamlı bir farklılık bulunmaktadır $(\mathrm{p}=0,032<0,05)$. Kadınların ortalamasının daha yüksek olması kadınların internetten alışveriş yaparken öznel normlardan erkeklere göre daha çok etkilendiğini göstermektedir. " $\mathrm{H}_{11}$ : İnternet üzerinden alışverişte tüketicilerin cinsiyetlerine göre öznel norm farklılık gösterir." hipotezi kabul edilmiştir.

\section{Sonuç ve Öneriler}

Günümüz dünyasında sınır kavramının teknolojiyle beraber ortadan kalktığını, klasik pek çok kavram ve tanımın bilgi ve iletişim teknolojilerine endeksli olarak değişmeye başladığını görmekteyiz. İnsanların ihtiyaçlarını giderdiği klasik mağaza imajının da teknolojiyle birlikte değişmesiyle internet üzerinden alışverişi mümkün kılan e-ticaret siteleri de hızlı bir şekilde ortaya çıkmış ve çıkmaya da devam etmektedir. Yapılan alışverişlerin geleneksel alışverişten sanal alıverişe doğru hızla yayılmasıyla e-ticarette tüketicilerin satın alma niyetlerini etkileyen faktörlerin araştırılması önem kazanmaktadır.

İnsan ve otomasyon arasındaki ilişkinin dinamikleri, gelişen teknolojilerin performansı ve hayatta kalması açısından kritik öneme sahiptir (Ghazizadeh vd., 2012). Hem TAM hem de TPB, tüketicilerin çeşitli teknolojilerin benimseme niyetlerini etkileyen faktörleri araştırmak isteyen araştırmacılar tarafından kullanılmaktadır. Bu çalışmada, TAM ve TPB modelleri dikkate alınarak İnternet üzerinden alışveriş yapan tüketicilerin, satın alma niyetleri üzerinde etkili olan faktörler tespit edilip, katılımcıların bu faktörlere demografik özelliklerinden cinsiyet bazında farklı bakıp bakmadıklarına yönelik davranışlarını ortaya koymaya çalışılmıştır. Araştırma kapsamında ilgili literatür çalışmasında, tüketici davranışları ile ilişkisi olduğu düşünülen; algılanan kullanım kolaylığı, algılanan haz, algılanan güven, algılanan kullanışlılık, öznel norm, algılanan davranışsal kontrol bağımsız değişkenleri ve davranışsal niyet bağımlı değişkeni irdelenmiştir. Regresyon analizi sonucunda elde edilen bulgular; algılanan davranışsal kontrol dışında diğer faktörlerle ilgili hipotezlerin yüksek anlamlılık seviyeleri TAM ve TPB teorilerini istatistiksel olarak desteklemektedir (Kim vd. 2008; Lu vd.2010; Ramayah ve Ignatius 2005; Joo ve Sang 2013). Ayrıca davranışsal niyet açısından en önemli faktörün algılanan kullanışlılık olduğu belirlenmiştir.

Araştırma bulguları, tüketicilerin internet üzerinden satın alma davranış niyetlerinde algılanan haz, sosyal norm ve algılanan güven bakımından anlamlı cinsiyet farklılıkları bulunduğunu ortaya koymaktadır. İnternetten alışveriş yapan tüketicilerin cinsiyeti ile algılanan haz arasında pozitif yönlü bir ilişki olduğu bulunmuştur. Araştırma bulguları kadınların erkeklere göre internetten alışveriş yapmaktan daha fazla haz aldıklarını göstermektedir. $\mathrm{Bu}$ bulgu literatürdeki Campbell (1997), Özgüven (2011), Aydın ve Derer'in (2015), çalışmalarıyla uyum göstermekle birlikte Akçi ve Annaç Göv (2015), çalışmalarıyla çelişmektedir. İnternetten alışveriş yapan tüketicilerin cinsiyeti ile algılanan güven arasında da pozitif yönlü bir ilişski bulunmakta olup erkeklerin ortalaması kadınların ortalamasından daha yükssek çıkmıştır. Buna göre erkeklerin internetten alışverişi kadınlara göre daha güvenli bulduğunu ifade edebiliriz. Kadın tüketiciler internetten alışveriş yapmayı keyifli bulmalarına rağmen güvenlik konusunda erkeklere göre daha endişeli bir tutum sergilemektedirler. Bu bulgu literatürdeki Demirel (2010), Bae ve Lee (2011), Yılmaz ve Tümtürk (2015) çalışmalarıyla uyum göstermektedir. İnternetten alışveriş yapan tüketicilerin cinsiyeti ile öznel norm arasında da pozitif yönlü bir ilişki olduğu görülmüş̧ür. Bu sonuca göre kadınların internetten alışveriş yaparken öznel normlardan erkeklere göre daha çok etkilendiğini ifade edebiliriz. Yani kadınların internet üzerinden alışveriş yapmalarında kendilerine yakın gördükleri ve fikirlerine önem verdikleri kişilerin görüşleri 
oldukça önem taşımaktadır. Elde edilen bu bulgu literatürdeki Garbarino ve Strahilevitz (2004), Bae ve Lee (2011), Venkatesh ve Morris (2000), Goswami ve Dutta (2016), çalışmalarıyla uyum göstermekle birlikte Yılmaz ve Tümtürk (2015) ve Wang vd. (2009) çalışmalarıyla çelişmektedir. Ağızdan ağıza iletişim kadınlarda erkeklerden daha güçlü bir etkiye sahip olmaktadır.

Sonuç olarak bu çalışmada, algılanan kullanışlılık, algılanan kullanım kolaylığı, algılanan haz, algılanan güven ve öznel normun tüketicilerin internetten alışveriş yapma niyetleri üzerinde anlamlı bir etkisinin olduğu ortaya koyulmuştur. Ayrıca algılanan haz, öznel norm ve algılanan güven bakımından kadınlar ve erkekler arasında anlamlı farklılıklar ortaya çıkmıştır. Bu sonuçlar çerçevesinde, işletmelerin e-ticarette başarı yakalamalarına katkı sağlayacağı düşünülen önerileri şu şekilde sıralayabiliriz:

- Algılanan kullanım kolaylığının, tüketicinin internetten alışveriş niyetine etkisinin yüksek olması nedeniyle internet üzerinden satış yapan işletmeler, web sitelerini, tüketicilerin en kolay şekilde kullanabilecekleri bir şekilde düzenlemelidir. Satış işlemleri basit tutularak tüketicinin zaman kazanması sağlanmalıdır. Ürünler ile ilgili yeni ve son bilgilere yer verilmesi, web sitesinin içeriğinin güncel tutulması ile tüketicilerin işletmeye güven duyması sağlanabilir.

- İşletmeler, garanti ve müşteri şikayetlerini ele alma konusunda anlaşılması kolay bir politika geliştirmelidirler. Tüketicilerin internetten alışverişi gerçekleştirmeden önce sahip oldukları hakların açık bir şekilde belirtilmesi, müşteri şikayetlerinde, işletmelerin, yayınlanan müşteri politikasına uygun olarak davranmaları müşterinin güvenini kazanmaları açısından oldukça önemlidir. İşletmelerin, müşteri bilgilerinin gizliliğinin korunduğu, güvenli bir ödeme alt yapısının olduğu gibi konularda açıklayıcı bilgiler vererek internet üzerinden alışveriş yapmanın güvenilirliği konusunda erkeklere göre daha endişeli olan kadınları ikna etmek için daha fazla çaba harcamaları gerekmektedir.

- İnternet üzerinden satış yapan işletmelerin, erkeklere göre çevresindeki kişilerin yorumlarından daha fazla etkilenen kadın tüketicileri etkilemek için bilginin hızlı bir şekilde yayıldığ 1 sosyal medyayı doğru yönetmeleri son derece önemlidir. İşletmelerin satış yaptıkları web sitelerine entegre edilmiş sosyal medya hesapları, tüketicilerin işletme ile çift yönlü iletişim kurmasını sağlayarak ürün ve hizmetler hakkında daha fazla bilgi sahibi olmalarına imkan tanıyacaktır. Ayrıca ürünü daha önce kullanan müşterilerin yorumlarına web sitesinde yer verilmesi işletmeye olan güvenin artmasında etkili olacaktır.

- Kadınların alışverişten daha fazla haz almaları erkeklere göre daha fazla zaman harcadıkları anlamına gelmektedir. Bu nedenle, online satış yapan işletmelerin, kadın tüketicilerin daha fazla katılımını sağlayacak, onları cezbedecek pazarlama iletişimi çalışmaları yapmaları önemli bir konudur. Kadın tüketicilere yönelik ürünlerde çekiliş, promosyon, yarışma gibi alışverişi daha keyifli hale getirecek pazarlama faaliyetlerinde bulunmaları kadınların online alışveriş miktarının artmasına katkı sağlayabilir.

$\mathrm{Bu}$ çalışma, Niğde Ömer Halisdemir Üniversitesi'nde çalışan akademik ve idari personeller ile sınırlıdır. Bu durum çalışmanın fiziksel kısıtı olarak öne çıkmaktadır. Daha geniş bir örneklem üzerinde farklı yaş grupları, farklı meslekler, farklı gelir grupları dikkate alınarak yapılacak çalışmalarla sonuçların genellenebilmesi sağlanabilir. Gelecekteki çalışmalara, satın alma niyeti üzerinde bu çalışmada ele alınmayan farklı kontrol değişkenleri de eklenebilir. 


\section{Kaynakça}

Ac1lar, A. (2016). E-Commerce in Turkey, Global Business Research Congress (GBRC - 2016), (2): 281-288.

Ajzen, I. (1991). The Theory of Planned Behavior, Organizational Behavior and Human Decision Processes, (50): 179-211.

Akçi, Y. ve Göv, S. (2015). Tüketicilerin E-ticaret Algılarının İncelenmesi (Gaziantep ve Adıyaman Örneği), Mehmet Akif Ersoy Üniversitesi Sosyal Bilimler Enstitüsü Dergisi 7(13): 413-433.

Al-Somali, S. A., Gholami, R., ve Clegg, B. (2009). An investigation into the acceptance of online banking in Saudi Arabia, Technovation, 29: 130-141.

Aydın, S. ve Ezel D. (2015). E-Ticarette Güven Unsurunun Müşterilerin Satın Alma Davranışlarına Olan Etkisi: Süleyman Demirel Üniversitesi Öğrencileri Üzerine Bir Araştırma, Süleyman Demirel Üniversitesi Sosyal Bilimler Enstitüsü Dergisi, 1(21): 127-150.

Bae, S. ve Lee T. (2011). Gender Differences in Computer's Perception of Online Consumer Views, Electronic Commerce Research, 11: 201-214.

Campbell, C. (1997). Shopping, Pleasure and Sex War, The Shopping Experience, London: Sage.

Chen, C.C. (2013), The exploration on network behaviors by using the models of Theory of planned behaviors (TPB), Technology acceptance model (TAM) and C-TAM-TPB, African Journal of Business Management, 7(30): 2976-2984.

Chen, L., Gillenson, M.L. ve Sherrell, D.L. (2002). Enticing Online Consumers: An Extended Technology Acceptance Perspective, Information \& Management, 39(8): 705-719.

Davis, F.D. (1989). Perceived Usefulness, Perceived Easy of Use and User Acceptance of İnformation Technology, MIS Quarterly, 13(3): 319-340.

Davis, F.D., Bagozzi, R.P., ve Warshaw, P.R. (1992). Extrinsic and Intrinsic Motivation to Use Computers In The Workplace, Journal Of Applied Social Psychology, 22(14): 1111-1132.

Demirel, H. (2010). Üniversite Öğrencilerinin Elektronik Alışveriş Hakkındaki Görüşleri, Gazi Üniversitesi İktisadi ve İdari Bilimler Fakültesi Dergisi, 12(3): 119-134.

Elvalda, A., Lü, K. ve Ali, M. (2016), Perceived Derived Attributes of Online Customer Reviews, Computers in Human Behavior, 56: 306-319.

E-Ticaret Raporu (2017). http://www.eticaretraporu.org/wp-content/uploads/ 2017/04/TUSIAD_E-Ticaret_Raporu_2017.pdf (Erişim tarihi: 20.05.2018).

Fischer, E. ve Arnold, S.J. (1990). More Than a Labor of Love: Gender Roles and Christmas Gift Shopping, Journal of Consumer Research, 17(3): 333-345.

Fortes, N. ve Rita, P. (2016), Privacy Concerns and Online Purchasing Behaviour: Towards an Integrated Model, European Research on Management and Business, (22): 167-176.

Garbarino, E. ve Strahilevitz, M. (2004). Gender Differences in the Perceived Risk of Buying Online and the Effects of Receiving a Site Recommendation, Journal of Business Research, (57): 768-775.

Ghazizadeh, M., Lee, J., ve Boyle, L. (2012). Extending The Technology Acceptance Model To Assess Automation, Cognition, Technology \& Work, 14(1): 39-49.

Goswami, A. ve Dutta, S. (2016). Gender Differences in Technology Usage-A Literature Review, Open Journal of Business and Management, (4): 51-59. 
Ha, N.T., Nguyen, T.L.H., Nguyen, T. P.L. ve Nguyen T.D. (2019), The effect of trust on consumers' online purchase intention: An integration of TAM and TPB, Management Science Letters, (9): 1451-1460.

Jones, S., Johnson-Yale, C., Millermaier, S. ve Pérez, F.S. (2009). US College Students' Internet Use: Race, Gender and Digital Divides, Journal of Computer-Mediated Communication, (14): 244-264.

Joo, J. ve Sang, Y. (2013). Exploring Koreans' Smartphone Usage: An Integrated Model of The Technology Acceptance Model and Uses and Gratifications Theory, Computers in Human Behavior, (29): 2512-2518.

Kim, D., Ferrin, J., Donald L. ve Rao, H.Raghav (2008). A Trust-Based Consumer DecisionMaking Model in Electronic Commerce: The Role of Trust, Perceived Risk and Their Antecedenta, Decision Support Systems, 44(2): 544-564.

Kim M.J., Chung, N. ve Lee, C.K. (2010). The effect of perceived trust on electronic commerce: Shopping online for tourism products and services in South Korea, Tourism Management, 32 (2): 256-265.

Lee, D., Park, J. ve Ahn, J. (2001). On the Explanation of Factors Affecting E-Commerce Adoption, Twenty-Second International Conference on Information Systems, 109-120.

Lee, M.C. (2009), Factors Influencing the Adoption of Internet Banking: An integration of TAM and TPB with Perceived Risk and Perceived Benefit, Electronic Commerce Research and Applications.

Legris, P., Ingham, J. ve Collerette, P. (2003). Why do people use information technology? A critical review of the technology acceptance model, Information Management, 40(3): 191-204.

Li, Y., Qi, J. ve Shu, H. (2008). Review of relationships among variables in TAM, Tsinghua Science \& Technology, 13(3): 273-278.

Lu, C.T., Huang, S.Y. ve Lo, P. Y. (2010). An empirical study of on-line tax filing acceptance model: Integrating TAM and TPB, African Journal of Business Management, 4(5): 800-810.

Madden, T.J., Pamela S.E. ve Ajzen I. (1992). A comparison of the Theory of Planned Behavior and the Theory of Reasoned Action, Personality and Social Psychology Bulletin, 18(1): 3-9.

Mathieson, K. (1991). Predicting user intentions: Comparing the Technology Acceptance Model with the Theory of Planned Behavior, Information Systems Research, 2(3): 173-191.

Mokhlis, S. ve Salleh, H.S. (2009). Consumer Decision- Making Styles in Malaysia: An Exploratory Study of Gender Differences, European Journal of Social Sciences, 10(4): 574584.

Özgüven, N. (2011). Tüketicilerin Online Alışverişe Karşı Tutumları ile Demografik Özellikleri Arasındaki İlişkinin Analizi, Karamanoğlu Mehmet Bey Üniversitesi Sosyal ve Ekonomik Araştırmalar Dergisi, 13(21): 47-54.

Pavlou, P.A., ve David W. S. (2000). Measuring the effects and effectiveness of interactive advertising: A research agenda, Journal of Interactive Advertising, 1(1): 61-77.

Pikkarainen, T., Pikkarainen, K., Karjaluoto, H. ve Pahnila, S. (2004). Consumer Acceptance of Online Banking: An Extension of The Technology Acceptance Model, Internet Research, 14(3): 224-235.

Ramayah, T. ve Ignatius, J. (2005). Impact of Perceived Usefulness, Perceived Ease of Use and Perceived Enjoyment on the Intention to Shop Online, Journal of Systems Management (IJSM), 3(3): 36-51. 
Serhateri, A. (2015). Elektronik Ticarette Güvenliğin Tüketicilerin İnternet Üzerinden Alışveriş Yapma Tutumlarına Etkisi: Kocaeli Örneği, Karadeniz Dergisi, (27): 227-249.

Shih, Ya-Yueh ve Kwoting Fang (2004), The use of a decomposed Theory of Planned Behavior to study internet banking in Taiwan, Internet Research, 14(3): 213-223.

Shirley, T. ve Todd, P. (1995). Decomposition and crossover effects in the Theory of Planned Behavior: A study of consumer adoption intentions, International Journal of Research in Marketing, 12(2): 137-155.

Şahin, F. ve Alkaya, A. (2017). Tüketicilerin Çevrimiçi Şikayet Kanallarını Kullanımına Yönelik Davranışlarının: Teknoloji Kabul Modeli ve Planlı Davranış Teorisi Bütünleşik Modeli Bakış Açısı ile İncelenmesi, PESA Uluslararası Sosyal Araştırmalar Dergisi, 3(4): 87-103.

Thompson, T., Vivien, S.H., Lim, K.G ve Raye Y.C Lai (1999). Intrinsic and extrinsic motivation in Internet usage, Omega, 27(1): 25-37.

TUIK (2017), http://www.tuik.gov.tr/HbPrint.do?id=24862 (Erişim tarihi: 20.05.2018)

Türker, A. ve Türker Özaltın, G. (2013). Turistik Ürün Satın Alma Davranışının Teknoloji Kabul Modeli ile İncelenmesi, Dokuz Eylül Üniversitesi Sosyal Bilimler Enstitüsü Dergisi, 15(2): 281-312.

Ustasüleyman, T., ve Eyüboğlu, K. (2010). Bireylerin Internet Bankacılığını Benimsemesini Etkileyen Faktörlerin Yapısal Eşitlik Modeli ile Belirlenmesi, BDDK Bankacılık ve Finansal Piyasalar, 4(2):11-38.

Uzel, E. ve Aydoğdu, F.C. (2010). Çalışanların Elektronik Alışverişe Bakış Açıları Hakkında Kalitatif Çalışma, Organizasyonlar ve Yönetim Bilimleri Dergisi, 2(1): 19-25.

Venkatesh, V. ve Morris, M.G. (2000). Why don't men ever stop to ask for directions? gender, social influences, and their role in technology acceptance and usage behavior, MIS Quarterly, 24(1): 115-139.

Venkatesh, V., Morris, M.G., Davis, G.B. and Davis, F.D. (2003). User Acceptance Of İnformation Technology: Toward A Unified View, MIS Quarterly, 27(3): 425-478.

Wang, Y.S., Wu, M.C. ve Wang, H.Y. (2009). Investigating the Determinants and Age And Gender Differences in the Acceptance of Mobile Learning, British Journal of Educational Technology, 40(1): 92-118

Yang, Kenneth C.C. (2005). Exploring factors affecting the adoption of mobile commerce in Singapore, Telematics and Informatics, 22(3): 257-277.

Yayar, R. ve Sadaklığlu, H. (2012). Kamu Çalışanlarının İnternetten Ürün Satın Alma Davranışları Üzerine Bir Araştırma, Business and Economics Research Journal, 3(3): 145157.

Yılmaz, C. ve Tümtürk, A. (2015). İnternet Üzerinden Alışveriş Niyetinin Etkileyen Faktörlerin Genişletilmiş Teknoloji Kabul Modeli Kullanarak İncelenmesi ve Bir Model Önerisi, Celal Bayar Üniversitesi IIBBF Yönetim ve Ekonomi, 22(2): 355-384.

Yılmaz, V., Çelik, H.E. ve Pazarlığlu, M.V. (2010). E-Ticarete İlişkin Tüketicilerin Risk Algısının Tutum ve Niyetler Üzerine Etkisi: Ordinal Yapısal Eşitlik Modeli, Aksaray Üniversitesi IIIBF Dergisi, 2(2): 49-63. 